\title{
KEK Law and Its Economic Implication
}

\section{Salamuddin Daeng}

Senior researcher of Asosiasi Ekonomi Politik Indonesia (AEPI)

\section{Abstract}

This article describes implications of Indonesia government policy regarding to Special Economic Zones in Batam. The pioneer of Special Economic Zones had been exist with the enforcement of constitution about free trade and free port. Facilities or convenience is a factor that will attract investors, through this facility, it is expected investors just simply come to the concern government to take care of all permits relating to the investment activities. On the other side, facilities or incentives provided by legislation to investors, such as privileges or special treatment in certain different outside SEZ areas, that is the tax holiday for a period of time, the suspension or exemption of import duty, including tax.

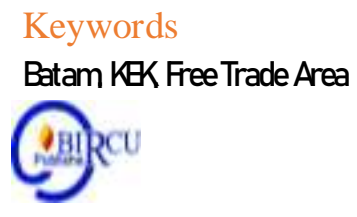

\section{Introduction}

\subsection{Stripping Enactment}

Not different from television daily movies, House of Legislatives (DPR) took chance of the days approaching their ending official term, enacting various neoliberal-sensed laws proposed by the executives. The DPR activities escaped from public notice, that were focused on the incumbent's cheats and devises subject to legislative and presidential election scandal.

One of so many laws enacted in general election season is the Law. No. 39/2009 on Special Economic Zone (KEK), ratified by DPR pleno session led by Agung Laksono the chairman on Tuesday, 15 September 2009. ${ }^{1}$

The law is a direct mandate from the Investment Law (UUPM) No. 25/2007. ${ }^{2}$ In Chapter XIV about KEK, article 21 of UUPM states that (1) TO accelerate economic development in certain area that is strategic for national economic development and to keep balance of a local progress, a KEK can be stipulated and developed. (2) The government has authority to determine a separate investment policy in a KEK. (3) Rules of KEK as meant in verse (1) will be regulated by Law.

According to KEK Law, a Special Economic Zone is an area with certain borders in the Republic of Indonesia jurisdiction, stipulated to hold economic function and obtain certain facilities, as mentioned in Chapter VI about Facilities and easiness, consists of 1) taxation, customs and duties, 2) local retribution and taxes, 3). Agrarian, license, immigration, and investment, 4) other easiness and facilites to be regulated by laws.

Various additional facilities and incentives given for investment through KEK law, exceeding what UUPM has given, whereas UUPM has before incited controversies among societies. Various elements state rejection because UUPM is blatantly in favour of big

\footnotetext{
${ }^{1} 1$ October 2009, vow being People Consultative's Assembly (MPR), House of Legislatives (DPR) and Regional Representative Board (DPD) for 2009-2014 period

${ }^{2}$ Ratified in Jakarta on 26 April 2007
} 


\section{Salamuddin Daeng: KEK Law and Its Economic Implication}

https://siasatiournal.com/index.php/siasat

investors especially foreigners, potential to damp Indonesian people economy. Most of Indonesian people rejection of UUPM is based on investment experience in New Order regime, making Indonesian economy be shrunk down.

\subsection{Learning from Batam FTZ}

KEK existence is not a new for Indonesian economy. Beforehand, various like special zones with like incentive and infrastructure supports have been made by the government. One of them is Batam. Starting with status as Pertamina operational and logistic base (1968), entrepot partikulir for export - import (1971), bonded warehouse/duty-free (1972), export processing zone (1978), bonded zone/ (1992), Free Tade Zone of Batam, Bintan, Karimun/BBK (2007).

Soon as UUPM was ratified, the government issued a regulation of Batam FTZ enforcement through Government Regulation in Lieu of Law No. 1/2007 on Free-Port and Free Trade Zone on the reason coercing emergency. [3] Government Regulation in Lieu of Law stipulates Changing on the Law No. 36/2000 about Government Regulation in Lieu of Law No. $1 / 2000$ on Free Port and Free Trade Zone becoming a Law. Government Regulation in Lieu of Law No. 1/2007 then becomes a base for determining Free Port and Free Trade Zone of Batam Bintan and Karimun (BBK). ${ }^{3}$

Different from two other zones, Bintan and Karimun in Riau Islands Province (Kepri) that has not been touched by modern infrastructure, FTZ of Batam is an example of a zone with the most incentive and facilities that has ever been before KEK Law is ratified. Both in infrastructure support, tax and duty import facilities, and easiness for foreign investors to control land, Batam has got facilities and incentives so similar as described of an FTZ in Law no. $39 / 2009$.

In the beginning, Batam area development itself was an ambi-tious project of New order Regime full of various corruption types. Ibnu Sutowo, JB Sumarlin, Habibie up to Batam Authority government period, various corruption scandal pushed in. Jeffrey A. Winters records various mega-corruption events in Batam history. In Ibnu Sutowo (1970) era, Batam was built in the view of blstering Pertamina oil business, although Pertamina got big profit but ended in bankruptcy due to corruption. Pertamina bankrupted bearing US\$ 15 billion of debt. In Habibie era (1978-1998), investment infrastructure mega-project construction beco-mes the corruption source of New Order crony both Habibie and CEndana families. As many as six giant bridges of $\mathrm{Rp} 400$ billion value, are built to connect uninhabited islands, a very large amount of money then. Besides, there are built ports, quays, and roads where New Order authorities and their cronies dredge profits. ${ }^{4}$

Their dream to make Batam as industrial base fails. Batam even becomes tracks for exporting oil and gas produced from natural resources. The infrastructure built just becomes facilities supporting Indonesia oil export. The condition still proceeds until today. The Government should have built oil and gas processing industries in order to support national industry.

Even the will to make Batam as competitor and economic surplus absorber of Singapore is like noon dream. What is happening now is contrary to it. Singapore is making use of various facilities given by Indonesian government in infra-structure, agrarian, taxation and labor to dredge economic profit. The country relocate non-environmental friendly factories to Batam in order to make "Made in Singapore" products. In Batam case, 43 percent

\footnotetext{
${ }^{3}$ Established in Jakarta on 4 June 2007

${ }^{4}$ Republic of Indonesia governmental regulation numbers 46, 47 and 48 in 2007, about free trade and free port zone of Batam, Bintan, Karimun, in Jakarta on 20 August 2007.
} 
of private investment there are foreign and 65.14 percent of the foreign investment are Singaporean capitals (2006).

In fact, the government has expended very costly between 1990- 2006, achieveing US\$2.43 billion or about +/- Rp 24.3 trillion, to build Batam. While the amount resulted from investment is not comparable. Statistic data issued by Batam Authority mentions central government tax revenue is only as much as Rp 1,23 trillion/year (2006). It means that central government expendi-ture is far larger than tax return.

What we see in Batam currently is apprehensive fact. Industrial buildings are very fragile because all capital goods, raw mate-rials and supporting goods are supplied from abroad, especially Singapore. Infrastructural facilities is not maximally taken advantage of. Hundreds of house-business buildings, offices, warehouses, ports, are emptily unoccupied. Even built bridges are not used. Batam is only used for location of dirty assembling industries of Singapore. While import duty facilities are just made use by Chine to steal textile export quota of Indonesia to the United States.

Industries do not grow as expected. What grow up are street-traders who are hauled everyday. Batam goes out of its track, changed into tourism area tending to be subject of sex and gambling business. Batam people admit that the most splendid time is when gambling is legalized there. As gambling was banded, Batam economy is slack immediately, except when there are new infrastructure project.

While areas surrounding Batam, like Bintan and Karimun for decades are target of dredging invesment, on bauxite, tin, granite, up to fuel in Natuna and export to Singapore, China and other industrial countries. The natural resource should have been used to support industrialization in Batam, even several small islands have disappeared because of mine and sand dredging to expand Singaporean land.

Without learning from the past, the government impressively goes on unresponsive, designing BBK FTZ. Unreasonable ideas reappear, the government plan to join BBK with imposing bridges. A breakthrough that will make corruption prevailing more. Current FTZ will not merely build export-oriented footlose industries, but also duty-free raw material and natural resource export track. This will give economic implication and also improve environmental destruction to small islands.

\subsection{Foreign Loan Projects}

In forthcoming years, Indonesia will be invaded by debts, part of solution scenario of global financial crisis and climate change issue address. Both are to be addressed by loan giving to developing countries in order to fight negative flow of global growth through infrastructural development and emission reduction.

Developed country measures seem to be in line with developing country leaders' thoughts, especially Indonesia that since the beginning like more debts for development, especially infra-structural development that is needed to support large scale investment in all economic sectors.

To realize KEK as meant by the law, the first thing to do is how to build needed infrastructures, like roads, bridges, ports, warehouses and others. Infrastructural procurement must cer-tainly need large spending budget. Such budget can not be procured from tax sources. Moreover fiscal stimulus policy that is broadening lately, and reduction policies of import duty and export duty in order to support free trade, have bring large pressure on the state revenue.

While state revenue from natural resource expecially oil and gas are slumping in accordance with national oil and gas production capacity reduction, the state revenue is virtually supported only by public payment, not by business elements. Most of the revenue 
will be sufficient only for routine spending such as salaries and benefits of civil servants from central to local ones

For infrastructural mega-project, the strategy is to take foreign debts, created by SBYBoediono. Debt signals for Indonesia was put forward in G20 London Summit, will be distributed through counter cyclical policy scheme as Indonesia suggested.

Loan signals for infrastructural development in Indoensia is uttered in Barack Obama speech as the US president received Peace Noble, stating commitment to build infrastructures, he mentioned Inodnesia and Korea in order to deal with unemployment in US. This means that Indonesia will receive loan for US crisis recovery program.

Indonesian economy dependency on foreing loan has been complicated problem. First, it is related with the loan size burdening the state budget to pay installment and interest that have been larger than Indoensian economy capacity. Second; the loan has created economic structure dedicating to foreign capital.

It has been public secret that most of the rules of law related with economic practice and systems are funded by foreign loan. As a result, the laws and regulations are tools for foreign capital to control Indonesian economy. One of the real examples is UUPM.

\section{Review of Literatures}

\section{Back to Colonial Exploitation Model}

Learning from investment experience along new order regime, various facilities and incentives given to investment. Since then, foreign investment rose sharply, controlling mining, farming and forestry sectors. Indonesia natural wealth was loaded abroad in order to support industrialization in developed countries. in global trade chain, Indonesia position as raw material supplier has not shifted within the last 200 years.

There are three main factors of Indonesia attractiveness for foreign investment. 1). Easiness in controlling large-scale lands, 2) natural resource and raw material exploitation for export. 2) cheap labor availability and fiscal incentives in order to build factories with capital goods, raw materials, and supporting goods import. KEK law ratification seems to aim to facilitate foreign capital. The government expects more foreign capital inflow to INDonesian economy, although today foreign capital has covered almost all economic sectors.

Investment Coordinating Agency (BKPM) data shows that foreign investment reaches 75 percent in the structure outside of mining and minteral, finance and banking sectors. While in mineral sector, almost 100 percent is controlled by foreigners, 85 percent in oil and gas and 70 percent in coal sector. While 95 percent of Bank Indonesia are controllable according to UUPM.

With various additional facilities given through KEK, foreign capital can be ascertained to dominate Indonesian economy, meaning that more natural resource to be dredged from Indo-nesian earth. The country will lose its basic capitals in building its own industries of oil and gas, steel and iron, and other manufacturing even of food.

Deindustrialization has been crucial problem in current Indonesian economy. Ine Minara Ruki (2007), states that Indonesia has experienced negative deindustrialization, a pheno-menon of declining contribution of industrial sector, conti-nuously before economy achieves industrialization phase.

Such phenomenon cause job becoming more difficult to get. On one side, agricultural labor experience a process called as deagrarianization, where peasant access to agrarian sources especially land will be more difficult because of large scale investment also infrastructure seizing peasants' land. 
While industry that should have been economic transformation target turns out not to have significant employment capacity. Extractive industries which is capital intensive and raw material export-oriented develop. More than half of economic employ-ment in Idnoensia works in informal sector with uncertained income. 13 percent among them work in industrial sector.

Besides, labor regulation in KEK law improves labor vulne-rability to mass dismissal. Regulation relating to labor union establishment in one company, three-party negotiation mecha-nism, certain working time agreement etc, open mass dismissal chances to happen is larger than general regulation such as Law no. 13/2003. The condition will incite higher unemployment rate, followed with more labor entering informal sectors and lower wages due to larger labor supplies in flexible job market.

In conclusion, KEK law is preserving colonial exploitation model that causes more natural resource drained of Indonesian earth, more labor paid cheaply and higher dependency to processed products and imported foods.

\section{Discussion}

\section{Negative Effects of Special Economic Zone (SEZ)}

Based on article 31 of Investment law no. 25/2007, in November 2008, the government proposed SEZ draftbill to the House of Legislatives. And like in same, in the middle of January 2009, a number of governors proposed their provinces to be decided as SEZ, also came to House of Legislatives. Their agenda : imposing the legislative power to soon ratify the bill. The governors wre sure that SEZ will secure economic progress into the land.

But, is it right that SEZ will bring in welfare, or it is contrarily touting meaningless objects for national competitiveness and economic progress, and give wide implications on social lives?

If the bill is imposed to become a law, it will cause negative impacts on social lives, among them are 1) giving benefits to big capitalists, (2) resource exploitation and economic surplus sucking, (3) destroying national industries, (4) burdening the state budget and foreign debts, (5) insigficantly reducing unemployment, and threatening workers' rights, (6) too wide fiscal facilities, (7) reducing local income, (8) agrarian conflict sources, (9) threatening living environments, and (10) neglecting national interest.

\section{Giving benefits to big capitalists}

As it is regulated under article 5 verse 1 of SEZ draft bill : " SEZ establishment can be proposed by a corporation, muni-cipality/regency administration or provincial government to the National Board"

(Private) Corporation existing and being permitted to establish SEZ will only give benefits to big capitalists both domestic and foreign ones. Moreover, such areas will be built in the view to attract foreign investment with various modern and complete infrastructural facilities, with attracti-ve fiscal incentives.

Batamindo Industrial Park (BIP) and Bintan Industrial Estate (BIE) are two areas built by Salim Group cooperating with Singapore Technologies Industries (now Semb Corp Industries) - subsidiary of singapure Temasek oldings - and Jurong Town Corporation (JTC) - a Singaporean prominent industrial infrastructure construction company.

BIP is an industrial area with 280 hectares of land, while Bintan Industrial Estate (BIE) projected to be built on 4,000 hectares of land, but since the first time of operation in 1994, the area does not experience any expansions more than 170 hectares. 
BIP and BIE development are deliberately meant as relo-cation for lowly valued product assembling activities from Singapore. In the beginning of 1980s decade - Singapore industry grew fast, so that the country needs site to relocate its industrial activities of low value.

Monetary Authority of Singapore (MAS) and Economic Development Board (EDB) research results recommended to choose Batam and other islands in Riau Islands (Kepri) province as the most logical alternative relocation to handle booming problem of Singapore industry then.

Later, Singapore did not only build industrial area, through Singapore Economic Development Board (SEDB) - a kind of Investment Coordinating Agency (BAPEPAM) of Indonesia the country also participated in promoting and marketing Batam aand Bintan areas to foreign investors. As a result, foreign investment traffic to the areas are controlled fully by SEDB. In relation with SEZ development plan in a number of areas, if SEZ draftbill is ratified, the government will re-cooperate with Singapore by making the example of Batam, Bintan and Karimun development as pilot project.

\section{Resource exploitation and economic surplus sucking logics}

By various fiscal and investment facilities given, SEZ is concerned not only to be a wide entrance for foreign capitals to exploit Idnoensia natural resources, but also to make foreigners more uncontrollable in doing various investment activities.

As contained in article 4 of SEZ bill; SEZ must be located at positions close to international trading line or close with international voyage course in Indonesia or at the favourite resource potential area.

In the case of Dumai SEZ development proposal, the area is apprehended to be a wide entrance for foreign investment to exploit Indonesia natural resources. Dumai is a city in Riau province, not at international trade line, despite having favourite resource : OIL.

Oil reserves in PT Caltex Pacific Indonesia (CPI) concession is estimated to remain about 28 billion barrels. Since operating in Riau in 1952, CPI has produced only 10 billion barrels. Even in 1973, CPI production could reach one million barrels per day, while current production is around 600 thousands to 700 thousands barrels per day.

On the other side, no certainty that a SEZ area performance drawing foreign investment correlates positively with its trading balance. Batam trading balance for instance, until the end of 2007 got loss. Total non-oil and gas exports during Jan-Nov 2007 as amounted to US\$7.3 billion while non-oil and gas import value to Batam during the same period is amounted to US $\$ 8.9$ billion. The trade data indicates that Batam has very high dependency on import.

Such condition is related to foreign investment in high-tech industries, such as pharmacy, chemicals, electronics, consumer goods, electrical equipments, which so far are not a truly manufacturing process, but only combining, packa-ging, and assembling. As a result, they have so high de-pendency on imports of raw materials, intermediary inputs, and other components. Such dependency is caused by no domestic supplies and supporting industries and the rela-tivity weakness of domestic production and industry.

SEZ like Batam at last only becomes fragile site for foreigners' sucking our economic surplus. The growing industries are only footloose ones that are massively low in usage of domestic raw materials and production factors, resulting in big debt needs due to a larger gap between import and export values. 


\section{Destroying national industries}

On the other part, import duty and tax exemption facilities which on the beginning intend to attract foreign investment just become the destroying factor of national industries. Batam experience shows that the area has just been misused by exporter and importer companies both domestic and foreign ones, as transit site for their products before they reexport to their real destinations.

As cited by daily Kontan of 30 October 2008 edition, Out-standing Goods and Service Monitoring Director of Trade Ministry Sahrul Sampurna said, that the governmet will take policy to close international trading through Batam Island for certain items like garments, electronics, foods and beverages, toys and shoes. Batam island is regarded as the most risky entrance of smuggled products to escape to Java Island, contributing to destruction of garment industries in Java.

For example, China's textile products exported to Batam, then there the product labels are changed into 'made in Idnoensia', then they are delivered to United States through Batam with $0 \%$ import duty preference. The export of 'made in Batam' China textile products have seized textile pro-ducers' quota in Java and other areas. Unfortunately, parts of them penetrates to markets in Java.

\section{Burdening the state budget and foreign debts}

SEZ development needs not small budget, while financing does not only comes from provincial/regency budget, but also national budget. Among the messy state finance, SEZ can be a pretext for the government to propose foreign debts again.

For example, Batam SEZ development funding so far turns out to come from foreign loans. Finance Ministry data reports that Batam Otorita batam (BOB) in 2007 are allocated the budget as much as Rp 282.4 billion, in $2008 \mathrm{Rp} 248$ billion, and in $2009 \mathrm{Rp} 215$ billion.

From Rp 282.4 bilion that is allocated for BOB activities in 2007, Rp 115 billion comes from foreign grants/loans. in 2008 the allocation decreases to Rp 248 billion, Rp 180 billion of which comes from foreign grant/loan (phln). For 2009, out of agreed fund of Rp 215 billion, Rp 75 billion of it comes from foreign loans. while for Sabang, allocation of 2007 as much as Rp 215 billion rises to Rp 441 billion in 2008 and Rp 421 billion in 2009 .

Such big budgeting will give more benefits if it is used for national oil industry infrastructure construction, than be used like now, only for other country's relocating their industry, entering Indonesia with low value in job creation and insignificantly contributing to national economy. If thoroughly observed, the costs expended by the government in building SEZ does not compare with revenue to receive.

\section{Insignificantly reducing unemployment, and threatening workers' rights}

Main argument of the government in SEZ establishment is to draw foreign investment, and increase job so that it will reduce poverty.but the reality is contrary. In Batam case, although foreign and domestic private investment shoes increasing trend, but it is low in job absorption. In 1998, total private investment reached US\$5,166 million, increasing into US\$ 5,351million in 1996, and in 2000 increased into US\$6,113 million, but the increasing trend is not followed by job absorption. In 1998, working class was absorbed by 53.02 percents, then declined to 41.76 percent in 1999 and down to 34.01 percent in 2000.

On the other side, the wages received by the workers is not comparable with descent living needs value (KHL). In 2008 Batam workers earn wages of Rp 960 thousands while KH L is Rp 1.4 million, so as in 2009, Batam Statistic Centre Agency (BPS) survey tatted that the city KHL is Rp 1.7 million, but minimum wages to earn was only Rp 1.04 million. 
The condition upholds poor people in Kepri province widening. In 2007, Kepri BPS shows that poor people numbers to 33.408 households from 700 thousands popu-lation. Also concerning one is cut workers' rights in SEZ, especially about organization rights. Article 43 verse 1 of SEZ bill regulates that in the SEZ will be established one labour union.

Article 43: Fighting for interest, to distribute workers' aspiration in SEZ, to be established 1 (one) labour union (2)Workers can become or not become members of the Labour Union.

Article 44: In a company that has established the labour union, to be convened a Common Working Agreement between the labour union and the businessman.

The Common Working Agreement contains among others rules or requirements of : a. Works that are done through worker supplying institutions or works that are given to other companies; b Rights and obligations of other parties.

The rationalization of labour organization numbers in SEZ, is meant to damp labours' flares and make companies easier in controlling the labour activities. This is in line with businessmen demand to secure investment climate. The rationalization is clearly contradictory to Labour Law (no. 13/2003), Labour Union Law (no.21/2000), and Industrial

\section{Too many fiscal facilities}

So wide facilities given to SEZ are not comparable to what government gains, moreover to what government will spend to construct on the area. Batam case shows that the tax revenue of the country is not proportional with potential loss from fiscal facility. UI LPEM data shows that 1998 potential loss of Batam is Rp 4.7 triliun, while tax revenue of 1999 reaches only Rp 874 billion. On the other side, total investment by the government until the end of 1999 as much as US\$1.6 billion raised from last year amount as US\$1.5 billion. SEZ development is clearly contradictory with governmental policies which each year stake tax revenue increase.

Table 1. Calculation of potential loss of BATAM Value-Added Tax

\begin{tabular}{|l|l|r|}
\hline \multicolumn{1}{|c|}{ Type of Good } & \multicolumn{1}{c|}{ Subject of Duty } & \multicolumn{1}{c|}{ Amount } \\
\hline Consumption Goods & Value added tax & 363.355 .522 .873 \\
\hline \multirow{2}{*}{$\begin{array}{l}\text { Raw Materials and } \\
\text { Capital Goods }\end{array}$} & Value added tax & 605.592 .538 .122 \\
\cline { 2 - 4 } All & Axport Violation & 182.395 .219 .150 \\
\cline { 2 - 3 } & $\begin{array}{l}\text { Import Duty } \\
\text { Sales Tax on Luxury }\end{array}$ & 3.027 .962 .690 .612 \\
\hline Tods & 545.194 .403 .592 \\
\hline Total & \multicolumn{2}{|c|}{4.724 .500 .374 .394} \\
\hline
\end{tabular}

Source: Merajut Batam Masa Depan, Heri Muliono, 2000 .

\section{Reducing local income}

SEZ development does not only reduce the state revenue because of fiscal incentive , and import duty, but also cause big potential to reduce local government revenue. Like SEZ draftbill article 34 verse 1:"Every Tax Payers who run business in SEZ are given exemption or discount of local tax and retribution according to rules of laws."

As a matter of fact, the area development requires adequate and complete infrastructure as contained in Article 4 part d of the draft SEZ bill. The infrastructure development certainly needs not small financing, while infrastructure maintenance and development finance as written in article 12 of the draft comes not only from the state budget but also local budget, 
will make local financial position more difficult both for funding the development and maintaining the infrastructure in SEZ itself.

\section{Agrarian conflict source}

SEZ establishment needing spacious land can become source of agrarian conflict. In January 2000, about 1000 villagers raided BIE and damped the generator, the month after in February 2000, Salim Group (one of BIE shareholders) was sued by Bintan peasants for illegal land seizing.

As reported by Voice of Human Rights, in India on 15 March 200711 peasants in Nandigram, 80 miles at south of Kolkata (formerly Calcutta) in Western Benggala, were dead after crash with security officers. The eviction of the peasants was related with local government to establish SEZ. It is refused by Bhumi Ucched Pratirodh (Land Takeover Resisting Committee) formed by Benggala peasants.

According to Amit Kiran Deb, a local government apparatus, as cited from Voice of Human Rights, since violence in Nandigram at the beginning of January 2008, 18 persons have died. While in 15 March 2007 crash, 39 injured, including 14 police and 11 peasants dead.

In SEZ establishment in a number of areas later, if the bill is ratified, such conflicts in India are probable to happen in land disputes for SEZ.

\section{Threatening living environments}

As published by Investor daily (7 January 2008), the govern-ment will not enact Presidential Regulation no. 111/2007 about Closed and Conditional Opened Business Sector List, or known as Investment Negative List in SEZ.

The governmental policy, is in accordance with article 37 or SEZ draft bill saying : "In SEZ it is not to enact the rules over conditional opened business in investment sector except those reserved for small and micro enterprises.

Without negative list, chemical industry that is risky in environmental destruction, such as: Penta Chlorophenol, Dichloro, Diphenyl Tricholoro Elhane (DDT), Dieldrin, Chlordane, Carbon Tetra, Chloride, Chloro Fluoro Carbon (CFC), Methyl Bromide, Methyl, Chloroform, Halon, and Chemical Industry of Skedul-I, Chemical Weapon Convention (Sarin, Soman, Tabun Mustard, Levisite, Ricine, Saxitoxin, VX, dll) can be established in SEZ. Such industries clearly put harm on living environment.

\section{Neglecting National Interest}

Besides Batam, SEZ practice also happens in Sabang, Aceh through the issuance of the Law no 3/1970 about Sabang Free Trade and Law no. 4/1970 about Sabang being stated as Free Harbour and Free trade Zone. And because Sabang was accused as smuggling gate, the government then issued Law no. 10/1985 lifting FTZ status from Sabang. Since then, Sabang has become common duty area as before.

Later, in 1998 Sabang city and Pulo Aceh district were made as Integrated Economic Development Area (Kawasan Pengembangan Ekonomi Terpadu/KAPET) by Presidential Decree No. 171 dated 28 September 1998. Further, in 2000, President KH. Abdurrahman Wahid era, the government issued Governmental Regulation in lieu of Law No. 2 in 2000 dated 1 September 2000 ratified then into the Law no 37/ 2000 about Sabang Free Harbour and Free Trade Zone. But in further development, performance of Sabang is not as expected, because the government is not serious enough in cultivating Sabang.

Geo-economically and geo-politically, Sabang is located more strategically than Batam, Bintan and Karimun. If Sabang was developed seriously by the government, it is probably 
able to bypass Malaka strait trading lane. Besides, if Kra-Mekong lane development in Thailand and Vietnam areas aiming to bypass the lane is completed, Indonesia can anticipate by developing Sabang free harbor.

Seeing the reality, the executive and legislatives must reconsider SEZ draftbill. The government needs to review SEZ enforcement in Batam, Bintan and Karimun Islands. Concession given to Singapore in developing the islands just put them as subordinate of Singapore.

In BBK development, the government must review BBK strategical position in relation to regional dynamics. BBK will grow better and faster if the zone is developed as oil industry logistic base, reminding its proper location to secure effi-ciency and effectiveness of oil and gas supplies.

As we know, when Ibnu Sutowo became Pertamina director, Batam and surrounding islands were planned as logistic and operational base of Pertamina in order to undertake explo-ration and exploitation of oil and gas. The basic reason of making Batam logistic centre, Ibnu Sutowo reasoned Pertamina base had still been in Singapore until 1960s decade. Then Pertamina did not only receive $85 \%$ revenue but also bear $85 \%$ contractor expense. Making Batam as oil logistic base, Pertamina was expected to save costs signi-ficantly, besides to save currencies and revive the state economy because Batam Base costs will be absorbed by domestic market.

Batam Main Plan was reviewed by Nissho Iwai Co.Ltd of Japan and Pacific Bechtel, Inc of the United States in 1972 and the review results in recommendation that Batam develop-ment strategy concentrates in oil and gas exploitation industry, and derivative product processing activities (petro-leum and petrochemical industrial centre). With geographical position right at the crosslanes of West and East Asia traffice, Batam is so strategic for benefitting from existing oil distribution line.

Responding to the plan, the government then made Batu Ampar (an area on Batam Island) as enterport partikulir area based on Presidential Decree No. 74/1971 based on Reglement A Ordonansi Bea (S. 1931 No. 471). But it is deviated later as what can be seen right now.

BBK development as oil industry and logistic base is supported by big oil and gas resource in vicinity. Natuna Archipelago - at north of BBK having oil reserves up to 298.81 million meter barrel oil (MMBO), and natural gas reserves as much as 55.3 trillion square cubic feet (TSCF). [4] at the west of BBK we have Dumai, Riau with oil reserves estimated to remain about 28 billion barrel. 6

Table 2. Gas, Condensate and Oil Production in Kepri Province

\begin{tabular}{rrrrr}
\hline Year Oil (Barrel ) & $\begin{array}{l}\text { Condensate } \\
\text { (Barrel) }\end{array}$ & Total (barrel) & Gas (MSCF) \\
\hline 2000 & $22,255,192.00$ & $10,779.00$ & $22,265,971.00$ & $42,404,063.00$ \\
\hline 2001 & $21,368,960.00$ & $247,646.00$ & $21,616,606.00$ & $66,371,520.00$ \\
\hline 2002 & $17,040,837.00$ & $245,279.00$ & $17,286,116.00$ & $98,922,052.00$ \\
\hline 2003 & $15,513,155.00$ & $277,481.00$ & $15,790,636.00$ & $146,582,424.00$ \\
\hline 2004 & $13,717,551.00$ & $362,367.00$ & $14,079,918.00$ & $162,060,637.00$ \\
\hline 2005 & $22,655,489.00$ & $2,510,957.00$ & $25,166,446.00$ & $175,222,373.00$ \\
\hline 2006 & $21,823,579.00$ & $287,480.00$ & $22,111,059.00$ & $164,037,138.00$ \\
\hline 2007 & $15,558,311.00$ & $530,538.00$ & $16,088,849.00$ & $125,640,489.00$
\end{tabular}

Source : Mineral Source and Energy Ministry 


\section{Conclusion}

In fact, to accelerate industrialization, we do not need SEZ establishment as many as possible, but the matter is how to restructurize national industry pattern towards resourcebased industry with minimal dependency on foreign components, and to improve maximally domestic component usage towards self-reliance so that the economy roots domestically, and confirm domestic market and purchasing power.

\section{References}

Batam Authority Agency and Batam Statistic Centre Agency, 2006

People Consultative's Assembly (MPR), House of Legislatives (DPR) and Regional Representative Board (DPD) for 2009-2014 period

Republic of Indonesia governmental regulation numbers 46, 47 and 48 in 2007, about free trade and free port zone of Batam, Bintan, Karimun, in Jakarta on 20 August 2007

This regulation ratified in Jakarta on 26 April 2007

Batam Authority Agency and Batam Statistic Centre Agency, 2006 